\title{
Liquidity and The Performance of The Nigerian Manufacturing Firms: An Economic Value-Added Approach
}

\author{
OLUSEGUN OSHO, ALEXANDER EHIMARE OMANKHANLEN, MOJISOLA \\ FASANMI, VICTORIA AKINJARE
}

\author{
${ }^{1}$ Department of Banking and Finance, Covenant University, Ota, NIGERIA
}

\begin{abstract}
Considering the possibility of finding a gap and a room for improvement, so much have been written about liquidity and performance. Notwithstanding, the emphasis has been on profitability as a yardstick for performance and little has been done on other areas of performance measurement. The emphasis has also been more on various economic sectors with the exception of the manufacturing industry. This paper intends to look at the impact, if any, of liquidity provision and availability on Nigeria's manufacturing firm's performance from the perspective of Economic Value Added (EVA). Economic value-adding is beyond just profitability or liquidity. The firm's value to the stakeholders, its sustainability and long-term values are defined. The study would apply liquidity theories, profitability and the economic value-added theories as it applies to a manufacturing firm in a developing economy like Nigeria. On its methodology, the article data is obtained from the World Bank's World Development Indicators-WDI and then a regression analysis will be run on the data using the SPSS software and then an analysis of the results of the regression. The last section of the article would conclude and make recommendations from the study outcome and the empirical analysis with respect to the theories.
\end{abstract}

Key terms: - Economic Value Added (EVA), manufacturing, liquidity.

\section{Introduction}

The manufacturing sector, within the real sector of an economy, is an important sector that should be working optimally to bring about increased productivity to an economy. And to achieve this optimal performance, the sector needs some inputs and operational resources which are determined, to an extent, by the amount of liquidity that is available for operational purposes. When talking about liquidity, the focus has been more on the other sectors of the economy other than the manufacturing sector and when talking about performance, the emphasis has been on profitability as a yardstick for performance and little has been done on other areas of performance measurement. Emphasis on the essence of liquidity has been more on the banking and financial sector just as the performance measurement tool has been on their profitability as affected by how liquid they are.

Consequently, much have been written on liquidity and profitability with respect to the banking and the financial sectors as against liquidity and other modern measures of performance and in other major sectors of the economy. Most of the previous studies, especially in Nigeria, were in that direction. [14] for example, conducted a study on liquidity analysis; these studies findings were mixed with a varying finding that there is a negative profitability association with liquidity, whereas other studies indicated the opposite. The study concluded that the relationship between profit 
growth \&liquidity variables is statistically significant.

\subsection{Statement of Problem}

There are established theories that Liquidity does not translate to profitability just as in all situations, profitability does not connote liquidity. Without actually being solvent, a corporation may be viable and a firm may be solvent without being viable. Liquidity should also be handled in order to achieve an optimum level, that is to say, a level that eliminates surplus liquidity, which can lead to management's lack of ideas. The level of liquidity should also not dip below the minimum standard, as it could contribute to the organization's failure to satisfy its short-term commitments [8]. Illiquidity and failure to make sufficient payments are one of the key factors that can trigger liquidation. Not necessarily profit as there is a good possibility that a company that is making profit can still go into liquidation [10]. Companies are designing diverse techniques to boost their liquidity role for value-adding purposes for these reasons. In order to boost liquidity and cash flows, techniques that can be applied within the organization concern working capital management, fields that is typically overlooked in periods of favorable market circumstances. Evaluating the relationship between liquidity management and economic value-adding of some selected manufacturing firms in Nigeria is the problem to be tackled by this research.

\subsection{Research Question}

According to the $(\mathrm{CBN})$, while there is an increase in the amount of credit made available to the manufacturing companies of $39.65 \%$, $5.39 \%$ and $27.62 \%$ in the years 2013 to 2014 , 2014 to 2015 and 2015 to 2016 respectively, the economic value added (percentage growth) for the manufacturing sector dropped from $21.80 \%$ to $14.72 \%,-1.46 \%$ and $-4.31 \%$ in the years 2013 to 2014,2014 to 2015 and 2015 to 2016 respectively. A mathematically inconceivable situation was when an increase in the amount of loan to the manufacturing sector from N2,
215.75 billion in the year 2016 also brought a negative value added of $-0.21 \%$. Then there is the need to see if an increase in the liquidity and credit within the Nigerian economy affects the performance of the manufacturing sector as regards their value-adding.

Then the following primary question arises;

1. To what extent did increased liquidity affect the economic value added of a manufacturing firm between 1990 and 2018 ?

2. To what degree did gross capital formation have an effect on the economic value adding to the firms in manufacturing sector between 1990 and 2018 ?

3. To what level did the prime lending rate as a major finance cost has an effect on the economic value adding to the firms in manufacturing sector between 1990 and 2018 ?

\subsection{Objective of the Study}

The primary research objective is to investigate empirically, the relationship between credit availability \& liquidity to the manufacturing firms and their performance with respect to economic value added between the years 1990 and 2018.

Some specific objectives of this research include:

1. To know if increased liquidity affected the economic value added of a manufacturing firm between 1990 and 2018.

2. To know if the gross capital formation had an effect on the economic value adding to the firms in manufacturing sector between 1990 and 2018.

3. To observe if the prime lending rate as a major finance cost had an effect on the economic value adding to the firms in manufacturing sector between 1990 and 2018. 


\subsection{Hypothesis of Study}

Therefore, the study hypothesis is based on the study's key objective of understanding the effect of liquidity on the economic value-added of the manufacturing sector.

The hypotheses are as follow:

1. H0: Liquidity did not affect the economic value added of manufacturing firms in Nigeria between 1990 and 2018.

H1: Liquidity did affect the economic value added of manufacturing firms in Nigeria between 1990 and 2018.

2. H0: Gross capital formation did not have effect on the economic value adding to the firms in manufacturing sector in Nigeria between 1990 and 2018.

H1: Gross capital formation had an effect on the economic value adding of the firms in manufacturing sector in Nigeria between 1990 and 2018.

3. H0: Prime lending rate as a major finance cost had no effect on the economic value adding to the firms in manufacturing sector in Nigeria between 1990 and 2018.

$\mathrm{H1}$ : Prime lending rate as a major finance cost had an effect on the economic value adding to the firms in manufacturing sector in Nigeria between 1990 and 2018.

\subsection{Scope of the Study}

The research scope covers the year 1990 through to the recent years up to the year 2018. This enables the study to look at the trend in order to study possible relationship and impact of liquidity on a firm's performance, using the Economic Value-Added approach. The study uses data on credit provided by the financial sector and to the private sector and assumes that the manufacturing sector takes a constant share of the provided credit and liquidity rather than using a more specific data on credit to the manufacturing sector.

\section{Literature Review}

According to [7] cash sufficiency, is important for every business just like the blood is important for the human body. Even if a business is fundamentally profitable, it cannot survive without the needed cash (liquidity) to pay wages and salaries and meet its obligation to suppliers. Numerous businesses have collapsed, even though profitable and with a good product, just because they have been unable to meet their debts. It becomes necessary for cash balance availability during the implementation of a strategy and that the proportion of the organisations' wealth tied up in capital terms, stock, work-in-progress and property does not squeeze out its demand for cash. Hence the need, when assessing company performance, is to ensure sufficient liquidity.

\subsection{Conceptual Review}

\section{Liquidity}

If it is willing to satisfy its financial commitments as and when due, an entity is considered to be liquid. Liquidity is essentially a bank's capacity to fund asset rises and also pay its obligations as and when they are due without incurring proportionately greater losses [6]. Liquidity is described as a firm's ability to meet its existing obligations with its current assets. A bank is solvent if, as it becomes due, it is able to satisfy its own commitments, refund deposits and make other payments dependent on the order of customers. Satisfying obligations on a short-term basis shows how liquid a firm is. When a firm possesses the capacity to transform assets to cash it is termed Liquid. Furthermore, it also relates to the pace at which it is possible to turn such properties into currency. Solvency, on the other hand, is the capacity of the organisation to satisfy long-term commitments that may require the redemption of both the principal and the lent fund's interest. Solvency has a close association with financial risk. The likelihood that the corporation will default on its long-term commitments increases as the 
organization's funding changes from equity to debt financing[12].

\subsubsection{Performance}

[12] organisations use different methods in measuring performance depending on their targeted goals and objectives. Multiple performance measures provide a more comprehensive picture of performance that considers a wide range of possibilities. Either for a division or an organisation as a whole, the examination of the implications of both the short-term and long-termdecisions guide in understanding the total performance potentials. Consequently, financial elements are not the only indicator for measuring performance of a firm. Non-financial measurement and the ease or flexibility of adapting to the changes of internal and external environments could also be measure of performance.Another problem in using just financial analysis, as against a value-adding approach, lies in the fact that value-creating activities are not identified by financial analysis. There are alternative performance measurement tools like customers' satisfaction, competitive advantage, product quality, resources and value creation. Basically, how the management of the firm handles these categories will determine financial implications for shareholders' value.

\subsubsection{Economic Value Added (EVA)}

Economic Value Added (EVA) is performance measurement that measures the economic profit of an organization and not the accounting profit. The focus of EVA is to determine the earnings that are above the required cost of capital for the shareholders and other providers of funds. If the firm earns more than the required rate of return, then value has been created for the shareholders. Economic Value Added (EVA) emphasizes the accounting profit minus economic or implicit costs. Unlike accounting costs or explicit cost that are expenditures that a firm makes to acquire the resources necessary for production, economic or implicit costs considers the opportunity costs of using the resources provided by the owners of the firm. EVA is often used by firms during the decision-making process when determining whether a large investment in plant and equipment should be made or not and whether it would be better for the owners of the firm to do such.[13], EVA could be used as a capital allocation tool for capital rational both for a firm and the economy at large. Using EVA, a minimal acceptable performance rate could be set as the expected return of the sector. A return below this average return means that the owners of the firm and the economy at large could have allocated their fund to another company or industry and be better off in terms of net-worth[13]

\subsubsection{Weighted Average Cost of Capital (WACC)}

Weighted average cost of capital (WACC) is the overall cost of a company's capital. To determine the WACC, the cost of each individual type of finance is weighted according to their proportions in the firm's finances. Market values are the standard basis for the proportions[8].Debt tends to reduce a firm's cost of capital since the debt tends to be less risky than equity. This advantage is enhanced by the fact that interest on debt is tax deductible, creating what is known as the 'tax shield' on debt. The averaged cost of capital, the total assets of the organisation and the operating profit after tax all affect the economic value added of a firm.

\subsubsection{The Manufacturing sector}

The manufacturing sector is a major sector in the real sector of an economy. It is crucial in how economiesconvertresources into work-inprogress and then finished goods that are value adding to all other agents of the economy[2] will require significantly more working capital than 
companies involved in retailing, or servicebased industries. A large manufacturing, for example, a car manufacturer, will typically have a long production cycle with significant number of raw materials, unfinished and finished goods, hence a high level of inventory. It will probably also offer a long credit period to customers and will therefore have a significant level of receivables as well. A retailer on the other hand will turn over inventory quickly and sales will often be mainly cash sales, resulting in much lower levels of inventory and receivables[8].

\subsection{Theoretical Underpinnings}

\subsubsection{The Liquidity Theories}

\section{Trade-off Theory}

Retaining Liquidity, cash held neither generates nor removes wealth under perfect stock market assumptions. When funds are sought, the company will constantly raise funds from the stock markets, there exist no transaction expenses when raising the funds, moreover the funds will always be collected at a reasonable price and it is presumed that the stock investors are well aware of the company's prospects. In order to offset the profit and expense of holding currency, the trade-off principle implies that businesses target an acceptable degree of liquidity. Because of the liquidity-premium and likely tax drawback, the expense of keeping cash requires a low-rate of return on these investments. The advantages of keeping cash lie in 2 ways: Companies save transaction-costs to raise funds and do not need to liquidate assets in order to pay for transactions, and if other sources of funding are not available or are extremely costly, the company may use liquid-assets to fund its activities \&investments [10]

\subsubsection{Clark's Profitability}

Theory

of

Clark postulates one of the profitability hypotheses with an overview of an economy operating without profit with simple potential considerations. According to the management pay standard, the fundamental assumptions in that type of economy are optimal business conditions i.e a perfect market mechanism; stagnant position, stable production variables, lack of hegemony, not vulnerable to adjustment and compensation. In a frictionless climate, there is an unrestricted movement of commercial operations, complete mobility and movement of all economic units, dissolving all barriers to complete competitiveness [14].

\subsubsection{Knight's Theory of Profit: Risk, Uncertainty and Profits}

A significant theory connects risk and uncertainty with profit. The benefit is compensation for confusion, according to $\mathrm{F}$. $\mathrm{H}$ Knight. F.B. Hawley \&A.C., also before Knight, Pigou had figured out that while they must bear the costs of development, entrepreneurs gain money. But the principle of income dependent on confusion has been greatly developed by Knight. On the one hand, he has contrasted between risk and instability and, on the other, stable and unexpected shifts. Dynamic changes, according to him, only give rise to benefit if changes and their effects are unforeseen. Profits are produced only by those changes whose occurrence cannot be determined beforehand

\subsection{Empirical Review}

[13] carried out a research in the Croatian economy on the literature and application of the concept of EVA and net profit. Their paper stated EVA as a financial performance measure that emphasizes the maximization of shareholders' value, as opposed to mere 
maximization of net profit.[13]. Their article did a good job on the concept of EVA and its application with a focus on the Croatian and economy. It mentioned that EVA could be different for individual industry or sector of the economy but was not specific to any sector of the economy. [4] pointed to the possibilities of using the Economic Value-Added index in evaluating the performance of the forest enterprise in Slovakia. Though their study worked well on EVA, comparing it to accounting profit, it focused on the forest enterprise in Slovakia. The article concluded that EVA could be applied in measuring performance for the firms in the forestry sector. [14] assessed the impact of liquidity and profitability ratios on growth of profits in Pharmaceutical firms in Nigeria.His study is one of the numerous studies on liquidity and profitability using the accounting ratios to determine and measure both liquidity and profitability.

According to his study [14], the relationship between liquidity and profitability is controversial.It stated that some studies draw the conclusion that liquidity and profitability are negatively related while others assert a positive relationship. Though the pharmaceutical sector is under the manufacturing industry, the study was just on the controversy about the trade-off between liquidity and profitability.[6] examined the trend of banks liquidity and the impact of bank liquidity on profitability of commercial banks in Ghana.

\section{$3 \quad$ Methodology}

Our source of data is the World Development Indicator (WDI) of the World Bank database and the statistical bulletin of the Central Bank of Nigeria (CBN). Annual data on the Manufacturing Value added as a percentage of the gross domestic product (GDP), loans given to the manufacturing sector, gross capital formation of the economy, lending rate and the inflation rate were collected for the study.

\subsection{Model Specification}

The model for the study is specified as follows:

$$
\begin{aligned}
& \text { MnfVA }=\beta 0+\beta 1 \text { MnfLoan }+\beta 2 \text { GrossCF }+ \\
& \beta 3 \text { PLR }+\beta 4 \text { InfRate }+\mu 2
\end{aligned}
$$

Where: MVA = Manufacturing Value Added, MnfLoan = Manufacturing Loan, GrossCF $=$ Gross capital formation, $\mathrm{PLR}=$ Prime lending rate, InfRate $=$ Inflation rate.

The quality of the regression model would be summarized by the squared multiple correlation. On the estimate technique, the modern econometric approach for analyzing relationship and data behaviors would be employed. We would adopt the Multiple Regression Model using the SPSS econometrics software.

\subsection{Empirical Results}

\subsubsection{Descriptive Statistics}

\section{Table 1}

\begin{tabular}{|l|r|r|r|}
\hline \multicolumn{4}{|c|}{ Descriptive Statistics } \\
\hline MnfVA & \multicolumn{1}{|c|}{ Mean } & Std. Deviation & \multicolumn{1}{c|}{ N } \\
MnfLoan & 2.4686 & 9.42409 & 29 \\
GrossCF & 1111.0731 & 2184.59262 & 29 \\
PLR & 28.8049 & 11.58885 & 29 \\
InfRate & 18.8566 & 3.30603 & 29 \\
\hline
\end{tabular}

The index of the manufacturing value added (MnfVA) in percentage averaged $2.47 \%$ between 1990 and 2018 in Nigeria and dispersed from a minimum of $-17.51 \%$ in 1993 to a maximum of 21.8\% in 2013.Manufacturing loan, (MnfLoan)also averaged 1111.07 billion.The minimum was7.88 billion in 1990and maximum was8922.97 billion in 2018 for the Nigerian manufacturing sector. Gross capital formation, (GrossCF), averaged 28.80billion ranging from 14.90 billionin 2013to53.19 billion in 1990 . Prime lending rate, (PLR), also averaged 
$18.86 \%$ and dispersed from a minimum of $13.54 \%$ in 1997 to a maximum of $29.8 \%$ in 1992. Inflation rate, (InfRate), averaged $18.46 \%$.
The minimum was5.38\% in 2007and maximum was $72.84 \%$ in 1995.

\subsubsection{Analysisof Estimated Coefficient}

\section{Table 2}

\begin{tabular}{|c|c|c|c|c|c|c|c|c|c|c|}
\hline & & & & el Summary & & & & & & \\
\hline \multirow[t]{2}{*}{ Model } & \multirow[t]{2}{*}{$\overline{\mathbf{R}}$} & \multirow[t]{2}{*}{ R Square } & \multirow{2}{*}{$\begin{array}{l}\text { Adjusted } \\
\text { R Square }\end{array}$} & \multirow{2}{*}{$\begin{array}{l}\text { Std. Error of } \\
\text { the Estimate }\end{array}$} & \multicolumn{5}{|c|}{ Change Statistics } & \multirow[t]{2}{*}{ Durbin-Watson } \\
\hline & & & & & $\begin{array}{l}\text { R Square } \\
\text { Change }\end{array}$ & F Change & df1 & $\mathrm{df2}$ & $\begin{array}{c}\text { Sig. } F \\
\text { Change }\end{array}$ & \\
\hline 1 & $\begin{array}{r}.6 \\
74 \\
a\end{array}$ & .455 & .364 & 7.51740 & .455 & 5.001 & 4 & 24 & .004 & 1.360 \\
\hline
\end{tabular}

a. Predictors: (Constant), InfRate, MnfLoan, PLR, GrossCF

b. Dependent Variable: MnfVA

A look at the regression result in Table 2 above, it shows that the regression coefficients as follows: MnfVA $=-6.742-0.001$ MnfLoan -0.355 GrossCF +1.354 PLR -0.293 InfRate

Albeit prime lending rate (PLR) has a positive coefficient, all other coefficients are negative with respect to manufacturing value added. The constant coefficient is a negative figure and this means that there would not be economic value adding in the manufacturing sector where manufacturing loan, gross capital formation, prime lending rate and the inflation rate are all zero. Also, a unit increase in the amount of manufacturing loan will lead to 0.001 decrease in the manufacturing value added (MnfVA). This is unexpected theoretically because one might expect that the more loans that are available to the manufacturing sector, the more they would be able to perform in terms of economic value adding. A unit increase in the gross capital formation (GrossCF) led to 0.355 decrease in manufacturing value added (MnfVA). This is also against apriori expectations because one would also expect that the more capital that is formed and available in the economy for the manufacturing sector, the more they would be able to perform in terms of economic value adding.

According to the result, there is a positive relationship between prime lending rate (PLR) and manufacturing value added (MnfVA).
A unit change in prime lending rate (PLR) leads to 1.354 increase in the in-manufacturing value added (MnfVA) and it is significant. And a negative relationship between inflation rate (InfRate) and manufacturing value added (MnfVA). Inflation has a negative effect on the manufacturing value added. Inflation increases the cost of capital and so an increased cost of capital and general cost of doing business would negatively affect the performance of a firm. This result confirms the expectations of inflation on economic value added of the manufacturing firms. Since, the t-cal values are less than the ttab, we reject $\mathrm{HO}$ and conclude that the parameter is statistically significant. In case of manufacturing loan, (MnfLoan), the T-cal 0.827 is lesser than T-tab 2.571 we reject $\mathrm{H} 0$. For gross capital formation, (GrossCF), the Tcal -2.074 is lesser than T-tab 2.571, we reject $\mathrm{HO}$ and conclude that the parameter is statistically significant. The same applies to prime lending rate (PLR) and inflation rate (InfRate) where their $\mathrm{t}$-cal are 0.475 and -0.533 and are less than the t-tab of 2.571. We therefore reject $\mathrm{H} 0$ and conclude that the parameters are significant. From the regression result, it was found out that coefficient of determination is about 0.455 . This implies that about $45.5 \%$ of the total variation in the manufacturing value 
added (MnfVA) is explained by MnfLoan, GrossCF, PLR and InfRate. The remaining $54.5 \%$ is accounted for by the error term in the model. This does not show a very good fit.

\section{Discussion of Results}

Considering the fact many studies have looked into the effects of liquidity on profitability, as a performance tool on different sectors and especially the financial sector, this study decided to use the economic value added (EVA) approach to measure the impact of liquidity on the performance of the manufacturing firms in Nigeria. The study used different theories and articles from previous authors to explain liquidity and economic value added (EVA) as a performance measurement tool. The study also got theories that show the connection between the two. The methodology adopted a secondary source of data from the WDI and the CBN statistical bulletin. From the results analysis, the study brought out that though liquidity affects the performance of the manufacturing firms in Nigeria using the economic value-added approach; there was noclear-cutpositive or negative relationship between them.

\section{Conclusion}

The study therefore concludes that liquidity does affect the performance of the manufacturing firms in Nigeria with respect to economic value added (EVA).Three out of the four independent variables that were used gave a negative and decreasing impact on the manufacturing valueadded as against a positive expectation that one could have. One can conclude from the study that rather than getting a complementary effect on economic value added, liquidity seems to be looking like there will be a trade-off decision between it and economic value added just like some authors have found with profitability. And if it is established, less liquidity would be required by managers and owners of manufacturing firms that desire economic value added.

\subsection{Recommendations}

1. On that premise, this study would lead to a recommendation that to achieve a better performance from the manufacturing companies in Nigeria in the long term and through value adding, policies that reduce the cost of capital and cost of finance as well as increasing motivation for capital formation and investments in new assets and deepening of capital formation would increase the value added of the sector.

2. Policies that reduce the cost of capital and cost of finance to the manufacturing firms should be implemented. This can be achieved by giving more targetachieving loans at subsidized rates.Policies that reduce the general inflation rate should be targeted. Government should encourage the increase in the productive capacity of all the sectors of the Nigeria economy especially through the private sector participation.

3. Manufacturing firms should be encouraged and monitored and motivated for capital formation and investments in new assets and deepening of capital formation would increase the value added of the sector.

4. Also, it recommends a further study of economic value added either in another sector of the economy in the Nigerian economy or elsewhere with an emphasis on a different methodology approach of using a primary source of data. This would be different from this study which has used a secondary source of data.The change of focus and methodology from a secondary source to a primary source of data might be a paradigm shift for this study, either by providing us with the same result or a different result, and thus adding more lights and knowledge to using an economic value-added approach to measure performance. 


\section{Author's Contribution}

1. OLUSEGUN OSHO; WRITINGORIGINAL DRAFT, METHODOLOY REVIEW \& EDITING

2. ALEXANDER EHIMARE OMANKHANLEN; SUPERVISION

3. MOJISOLA FASANMI; CONCEPTUALIZATION

4. VICTORIA AKINJARE; PROJECT ADMINISTRATION

\section{Acknowledgements:}

We want to acknowledge Covenant University Center for Research, Innovation and Development (CUCRID) for provision of enabling environment for this research.

\section{References}

[1] Achugamonu, B. U., Babajide, A. A., Olokoyo, F. O., \& Adesina, T. F. (2016). Has post consolidation of deposits money banks affected the real sector? Global Media Journal .

[2] Akinjare, V. A., Ojo, J. A., Adetiloye, K., \&Akinjare, O. A. (2019). The Effect of Domestic Savings on the Industrial Sector in Nigeria. IBIMA .

[3] Andabai, P. W., \& Eze, G. P. (2018). BANK CREDIT AND MANUFACTURING SECTOR GROWTH IN NIGERIA (1990-2017): A CAUSALITY INVESTIGATION. International Journal of Economics, Commerce and Management, VI.

[4] Balážová, E., \&Luptáková, J. (2015). Application of the Economic Value-Added index in the performance evaluation of forest enterprise. JOURNAL OF FOREST SCIENCE.

[5] CBN. CBN Statistical Bulletin.

[6] Chamler, R., Alhassan, M., Evans, A., \& Erasmus, D. G. (2018). The Impact of Liquidity on
Performance of Commercial Banks in Ghana. Academic Journal of Economic Studies.

[7] Cole, G. (1997). Strategic Management: Theory and Practice. Sussex: Seng Lee Press.

[8] Evans, D. (2011). A Student's Guide to Corporate Finance and Financial Management. Berkshire: Kaplan Publishing UK.

[9] Goel, U., Saurabh, C., \& Anil, S. K. (2015). Operating liquidity and financial leverage: Evidences from Indian machinery industry. Science Direct , 344 -350 .

[10] Owolabi, S., \&Obida, S. S. (2012). Liquidity Management and Corporate Profitability: Case Study of Selected Manufacturing Companies Listed on the Nigerian Stock Exchange. Business Management Dynamics.

[11] Poll, H. v., Booyse, N. J., Pienaar, A. J., Büchner, S., \& Foo, J. (2011). An overview of the implementation of Economic Value Added (EVA ${ }^{\mathrm{TM}}$ ) performance measures in South Africa. Southern African Business Review, 15.

[12] Review, S. C. (2018). Surgent CPA Review Business Environment \& Concepts. Surgent CPA Review LLC.

[13] Sabol, A., \&Sverer, F. (2017). A review of the economic value added literature and application. UTMS Journal of Economics.

[14] Umobong, A. A. (2015). ASSESSING THE IMPACT OF LIQUIDITY AND PROFITABILITY RATIOS ON GROWTH OF PROFITS IN PHARMACEUTICAL FIRMS IN NIGERIA. European Journal of Accounting, Auditing and Finance Research.

[15] Waswa, C. W., Mukras, M. S., \&Oima, D. (2018). Effect of Liquidity on Financial Performance of the Sugar Industry in Kenya. International Journal of Education and Research.

[16] WDI. World Development Indicators

\section{Creative Commons Attribution License 4.0 (Attribution 4.0 International, CC BY 4.0)}

This article is published under the terms of the Creative Commons Attribution License 4.0

https://creativecommons.org/licenses/by/4.0/deed.en_US 